\title{
Response of the carbon cycle in an intermediate complexity model to the different climate configurations of the last nine interglacials
}

\author{
Nathaelle Bouttes $^{1}$, Didier Swingedouw ${ }^{1}$, Didier M. Roche ${ }^{2,3}$, Maria F. Sanchez-Goni ${ }^{1,4}$, and Xavier Crosta ${ }^{1}$ \\ ${ }^{1}$ Univ. Bordeaux, EPOC, UMR 5805, 33615 Pessac, France \\ ${ }^{2}$ Laboratoire des Sciences du Climat et de l'Environnement, LSCE/IPSL, CEA-CNRS-UVSQ, \\ Université Paris-Saclay, 91191 Gif-sur-Yvette, France \\ ${ }^{3}$ Earth and Climate Cluster, Faculty of Science, Vrije Universiteit Amsterdam, Amsterdam, the Netherlands \\ ${ }^{4}$ EPHE, PSL Research University, 33615 Pessac, France
}

Correspondence: Nathaelle Bouttes (nathaelle.bouttes@1sce.ipsl.fr)

Received: 28 October 2016 - Discussion started: 8 November 2016

Revised: 16 November 2017 - Accepted: 6 December 2017 - Published: 2 March 2018

\begin{abstract}
Atmospheric $\mathrm{CO}_{2}$ levels during interglacials prior to the Mid-Brunhes Event (MBE, $\sim 430 \mathrm{kaBP}$ ) were around $40 \mathrm{ppm}$ lower than after the MBE. The reasons for this difference remain unclear. A recent hypothesis proposed that changes in oceanic circulation, in response to different external forcings before and after the MBE, might have increased the ocean carbon storage in pre-MBE interglacials, thus lowering atmospheric $\mathrm{CO}_{2}$. Nevertheless, no quantitative estimate of this hypothesis has been produced up to now. Here we use an intermediate complexity model including the carbon cycle to evaluate the response of the carbon reservoirs in the atmosphere, ocean and land in response to the changes of orbital forcings, ice sheet configurations and atmospheric $\mathrm{CO}_{2}$ concentrations over the last nine interglacials. We show that the ocean takes up more carbon during pre-MBE interglacials in agreement with data, but the impact on atmospheric $\mathrm{CO}_{2}$ is limited to a few parts per million. Terrestrial biosphere is simulated to be less developed in pre-MBE interglacials, which reduces the storage of carbon on land and increases atmospheric $\mathrm{CO}_{2}$. Accounting for different simulated ice sheet extents modifies the vegetation cover and temperature, and thus the carbon reservoir distribution. Overall, atmospheric $\mathrm{CO}_{2}$ levels are lower during these pre-MBE simulated interglacials including all these effects, but the magnitude is still far too small. These results suggest a possible misrepresentation of some key processes in the model, such as the magnitude of ocean circulation changes, or the lack of crucial mechanisms or internal feedbacks, such as those
\end{abstract}

related to permafrost, to fully account for the lower atmospheric $\mathrm{CO}_{2}$ concentrations during pre-MBE interglacials.

\section{Introduction}

Ice core data have shown that atmospheric $\mathrm{CO}_{2}$ concentration has been different during interglacials of the last 800000 years (Lüthi et al., 2008; Bereiter et al., 2015). Older interglacials before the Mid-Brunhes Event (MBE) around $430 \mathrm{kaBP}$, i.e. Marine Isotope Stages (MIS) 13, 15, 17 and 19 , are characterised by relatively lower atmospheric $\mathrm{CO}_{2}$, around $240 \mathrm{ppm}$, compared to more recent interglacials, i.e. MIS 1, 5, 7, 9 and 11, which have a higher $\mathrm{CO}_{2}$ level of around 280 ppm (Fig. 1a).

Proxy data such as the marine benthic foraminifera $\delta^{18} \mathrm{O}$ stack record, embedding both deep-sea temperature and ice sheet volume (Lisiecki and Raymo, 2005), indicate that older interglacials (pre-MBE) experienced a colder climate than the more recent ones (post-MBE). This tendency is also supported by individual $\delta^{18} \mathrm{O}$ and sea surface temperature (SST, derived from $\mathrm{Mg} / \mathrm{Ca}$ paleothermometry, alkenones or foraminifera assemblages) records from marine sediment cores (Lang and Wolff, 2011; Past Interglacials Working Group of PAGES, 2016), although some individual substages such as MIS 7c and 7e were colder than the post-MBE mean interglacial climate. 


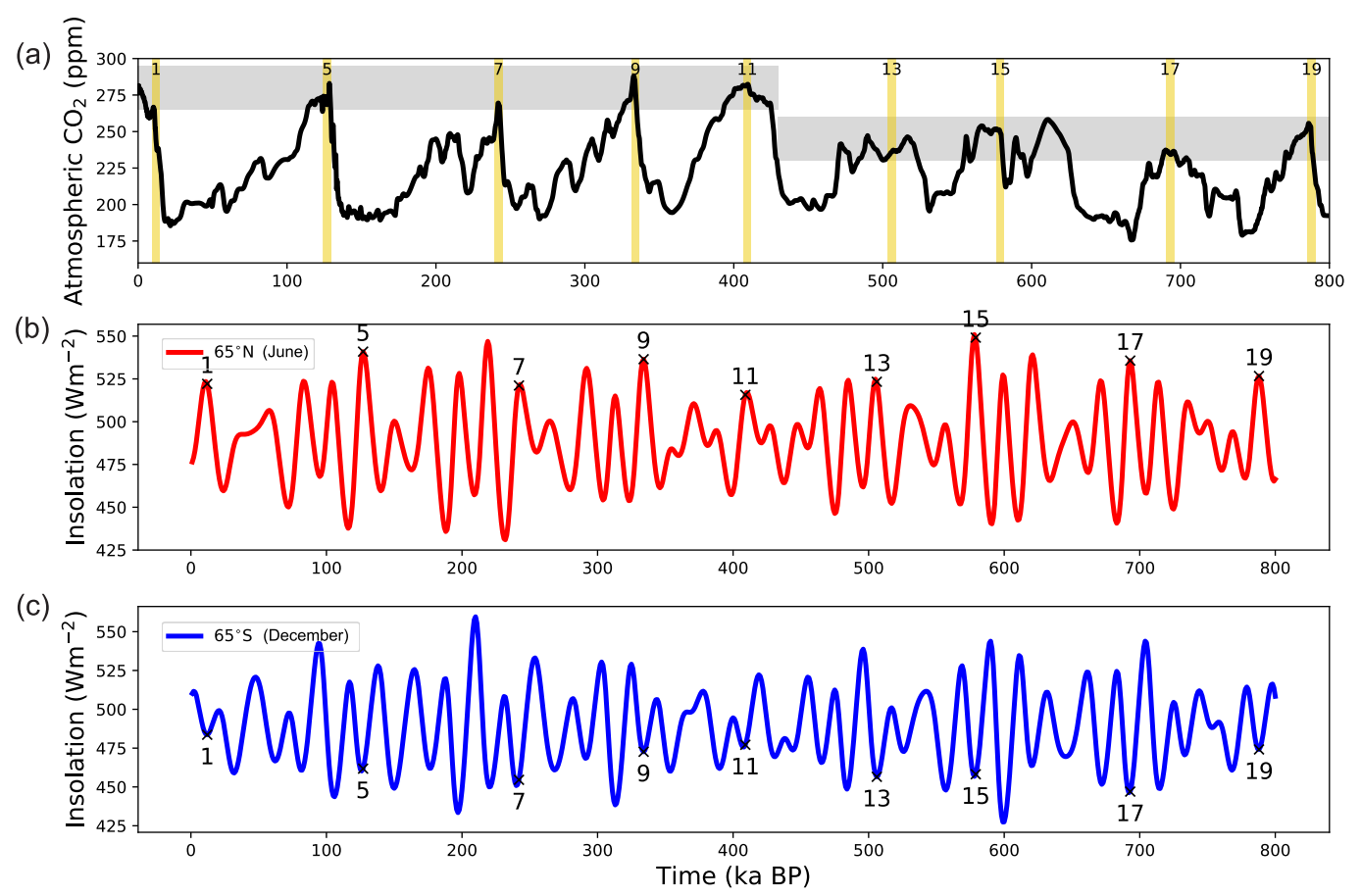

Figure 1. (a) Atmospheric $\mathrm{CO}_{2}$ (ppm) record at EPICA Dome C (Lüthi et al., 2008) and insolation (W m $\left.{ }^{-2}\right)(\mathbf{b})$ at $65^{\circ} \mathrm{N}$ on $21 \mathrm{June}$ and (c) at $65^{\circ} \mathrm{S}$ on 21 December, based on Berger (1978).

To explain the different climates of interglacials before and after the MBE, modelling studies have shown that it is necessary to include the change of atmospheric $\mathrm{CO}_{2}$ (Yin and Berger, 2010, 2012). Indeed, these numerical simulations with an intermediate complexity model have demonstrated that differences in Earth's orbital configuration, and hence seasonal and spatial distribution of insolation, alone cannot explain the colder climate recorded during pre-MBE interglacials, whereby lower atmospheric $\mathrm{CO}_{2}$ concentration is also necessary to simulate colder climate (Yin and Berger, 2010, 2012). However, the reasons for the lower $\mathrm{CO}_{2}$ values remain elusive and very few modelling exercises have tackled the issue of different $\mathrm{CO}_{2}$ levels during interglacials before and after the MBE. Köhler and Fischer (2006) have produced transient simulations of the last 740000 years using the BICYCLE box model. They used several paleoclimatic records such as ocean temperature, sea ice, sea level, ocean circulation, marine biota, terrestrial biosphere and $\mathrm{CaCO}_{3}$ chemistry to force their model forward. They run a set of simulations prescribing only one forcing at a time and another with all forcings excluding one at a time, which allows them to analyse which forcings are the most important. In their simulations, they have shown that the lower $\mathrm{CO}_{2}$ values during pre-MBE are mainly explained by the prescribed lower Southern Ocean sea surface temperature and weaker Atlantic meridional overturning circulation (low North Atlantic Deep Water formation and Southern Ocean vertical mixing) compared to post-MBE interglacials. Using an inter- mediate complexity model, Yin (2013) conversely simulated vigorous bottom water formation and stronger ventilation in the Southern Ocean during pre-MBE interglacials and suggested this could increase deep oceanic carbon storage and lower atmospheric $\mathrm{CO}_{2}$. However, this effect on the ocean carbon reservoir and atmospheric $\mathrm{CO}_{2}$ has not been evaluated yet in a climate model including a carbon cycle representation.

Changes in surface temperature also modify the partition of the carbon cycle: in the ocean, colder SST increases the solubility of $\mathrm{CO}_{2}$, increasing its potential uptake from the atmosphere during pre-MBE interglacials. In contrast, on land a colder climate might yield a decrease in biomass, reducing $\mathrm{CO}_{2}$ uptake via lower continental carbon storage. Because the ice sheets in the Northern Hemisphere are different during the interglacials in response to the different values of $\mathrm{CO}_{2}$ and orbital configurations (Ganopolski and Calov, 2011), they might also have an impact on the carbon cycle, for example by modifying the terrestrial biosphere extent.

Here, we test the impact of the different orbital configurations of the last nine interglacials on the carbon cycle. For this purpose, we use a coupled carbon-climate model to evaluate the changes of carbon storage in the ocean and in the terrestrial biosphere, as well as the impact of different Northern Hemisphere ice sheet volumes. 
Table 1. Dates of orbital parameters and $\mathrm{CO}_{2}$ used for the simulations (Lüthi et al., 2008), and sea level anomalies as compared to present-day conditions (m) corresponding to the prescribed ice sheets (Ganopolski and Calov, 2011).

\begin{tabular}{lrrrr}
\hline MIS & $\begin{array}{r}\text { Date of } \delta^{18} \mathrm{O} \\
\text { peak }(\mathrm{kaBP})\end{array}$ & $\begin{array}{r}\text { Date for orbital } \\
\text { configuration } \\
\text { and } \mathrm{CO}_{2}(\mathrm{kaBP})\end{array}$ & $\begin{array}{r}\mathrm{CO}_{2} \text { values from } \\
\text { data (ppm) }\end{array}$ & $\begin{array}{r}\text { Sea level changes (m) } \\
\text { corresponding to the } \\
\text { ice sheet configurations }\end{array}$ \\
\hline 1 & 6 & 12 & 243.2 & 13.8 \\
5.5 & 123 & 127 & 268.64 & -0.8 \\
7.5 & 239 & 242 & 269.23 & 5.6 \\
9.3 & 329 & 334 & 280.32 & -0.9 \\
11.3 & 405 & 409 & 282.29 & -0.8 \\
13.13 & 501 & 506 & 235.92 & 13.1 \\
15.1 & 575 & 579 & 249.36 & 2.3 \\
17 & 696 & 693 & 234.38 & -0.4 \\
19 & 780 & 788 & 242.73 & 10.8 \\
\hline
\end{tabular}

\section{Methods}

We use the iLOVECLIM climate model of intermediate complexity, which is a new development branch (code fork) of the LOVECLIM model in its version 1.2 (Goosse et al., 2010). iLOVECLIM has an atmosphere module (ECBILT) with a T21 spectral grid truncation $\left(\sim 5.6^{\circ}\right.$ in latitude-longitude in the physical space) and three vertical layers. The ocean component (CLIO) has a horizontal resolution of $3^{\circ}$ by $3^{\circ}$ and 20 vertical levels. The evolution of the terrestrial biosphere, i.e. the proportion of desert, grasses and tree cover, is computed by the VECODE model (Brovkin et al., 1997). It includes a carbon cycle module on land and in the ocean (Bouttes et al., 2015). iLOVECLIM is an evolution from the LOVECLIM model used in previous model studies of the last nine interglacials focused on climate (Yin and Berger, 2010, 2012; Yin, 2013). It has the same atmospheric and oceanic modules but includes a different carbon cycle representation in the ocean (Bouttes et al., 2015). We have chosen the same dates for the nine orbital configurations as in Yin and Berger (2010, 2012) and Yin (2013), i.e. the maximum of insolation preceding the $\delta^{18} \mathrm{O}$ peak values (Table 1, Fig. $1 \mathrm{~b}$ and c). Contrary to most simulations from these studies, we also use the $\mathrm{CO}_{2}$ values (as well as $\mathrm{CH}_{4}$ and $\mathrm{N}_{2} \mathrm{O}$ ) at the same dates as for the orbital configurations (and not at the $\mathrm{CO}_{2}$ peak), but as stated in Yin and Berger (2012), this may not affect the main results concerning the simulated climatic changes.

In the model, we separate the atmospheric $\mathrm{CO}_{2}$ concentration into two distinct variables depending on its physical and chemical impact. The first one is used in the radiative scheme of the atmosphere, for which we prescribe the $\mathrm{CO}_{2}$ from measured values in all the described simulations (Lüthi et al., 2008; Fig. 1a). Another atmospheric $\mathrm{CO}_{2}$ is computed interactively in the model as a result of the balance of the carbon fluxes between the different carbon subcomponents (atmosphere, ocean and terrestrial biosphere). We make this choice of keeping the two separated to ensure that the climate simulated by the model is coherent with past measured atmospheric $\mathrm{CO}_{2}$. In other words, we consider the atmospheric $\mathrm{CO}_{2}$ concentration as an imposed external forcing, while within the carbon cycle the atmospheric $\mathrm{CO}_{2}$ concentration is allowed to vary but does not impact the atmospheric radiative forcing. By doing this, we limit the number of degrees of freedom in our climate carbon system, which notably allows us to avoid the complication arising from simulating a different climate when the climate and carbon are fully coupled.

The simulations performed are snapshots, run with constant orbital and atmospheric $\mathrm{CO}_{2}$ concentration forcing and integrated over 3000 years, allowing the ocean to reach a quasi-equilibrium. All simulations start from the preindustrial control one, and the average of the last 100 years is used to analyse the results.

Our strategy is to evaluate the impact of the different climate and carbon compartments to set the atmospheric $\mathrm{CO}_{2}$ concentration. For this purpose, we consider three series of simulations, which have all been run for the nine interglacials (Table 2). The first series ("Ocean Carbon", OC) has fixed ice sheets set to the observed pre-industrial ones and a fixed terrestrial biosphere set to the simulated pre-industrial one. This first set of simulations thus provides the response of the ocean alone to the different orbital parameters and $\mathrm{CO}_{2}$ levels of the nine interglacials. The second series ("Ocean Vegetation Carbon", OVC) still has fixed ice sheets but includes an interactive terrestrial biosphere, computed by the model. It gives the response of both the ocean and land vegetation reservoirs to the different orbital parameters and $\mathrm{CO}_{2}$ as well as their interactions for setting the atmospheric $\mathrm{CO}_{2}$ concentration. Finally, the third series ("Ocean Vegetation Ice sheet Carbon", OVIC) has different prescribed ice sheets in the Northern Hemisphere for the nine interglacials. The ice sheet distribution change is based on modelling results, given that the uncertainty from data is very large for the interglacials of the last 800000 years, especially the oldest ones. The prescribed ice sheet distributions are thus taken from an ice sheet simulation of the last 800000 years (Ganopolski and Calov, 

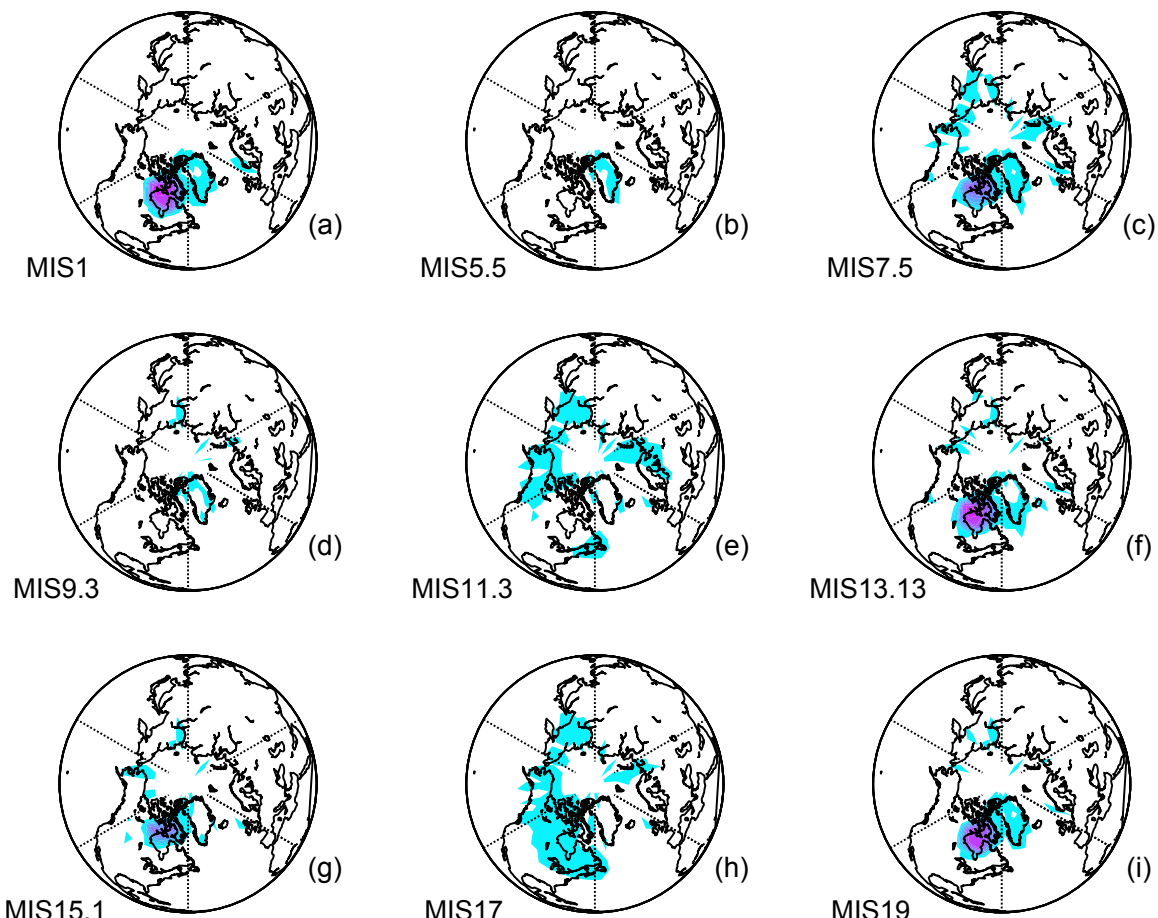

$(\mathrm{g})$

MIS15.1

MIS11.3

MIS13.13

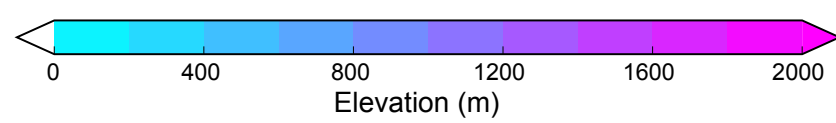

Figure 2. Ice sheet elevation $(\mathrm{m})$ in the Northern Hemisphere simulated by the CLIMBER-2 model (Ganopolski and Calov, 2011) and used in the OVIC series for each interglacial simulation, in anomalies with respect to the pre-industrial elevation.

Table 2. Summary of the three series of simulations.

\begin{tabular}{lccc}
\hline \multirow{2}{*}{ Name of the series } & \multicolumn{3}{c}{ Components impacting the carbon cycle } \\
\cline { 2 - 4 } & Ocean & Vegetation & Different interglacial ice sheets \\
\hline OC & $\checkmark$ & $\times$ & $\times$ \\
OVC & $\checkmark$ & $\checkmark$ & $\times$ \\
OVIC & $\checkmark$ & $\checkmark$ & $\checkmark$ \\
\hline
\end{tabular}

2011) using the intermediate complexity model CLIMBER2 (Petoukhov et al., 2000; Ganopolski et al., 2001; Brovkin et al., 2002), including a 3-D polythermal ice sheet model (Greve, 1997). This ice sheet model is coupled to the climate component via surface energy and mass balance interface (Calov et al., 2005), which accounts for the effect of aeolian dust deposition on snow albedo. The ice sheet distribution is chosen 2000 years after the chosen interglacial date to account for the long timescale of the ice sheet response during a deglaciation and to ensure that the ice sheet corresponds to an interglacial configuration. The ice sheet elevations for the nine interglacial simulations are shown in Fig. 2 and the corresponding sea level change in Table 1. The terrestrial biosphere is also interactive in this OVIC series of simulations. This last set of simulations thus adds the effect of having different ice sheets in the Northern Hemisphere for the carbon cycle variations.

\section{Results and discussion}

\subsection{Role of the ocean (OC simulations)}

Similar to previous numerical studies of the interglacials with the LOVECLIM model (Yin and Berger, 2010, 2012), the changes in orbital configuration and atmospheric $\mathrm{CO}_{2}$ altered SSTs and oceanic circulation for each interglacial simulation of the OC series. All simulations have warmer SSTs than the control pre-industrial in the Northern Hemisphere high latitudes (Fig. 3). Except for MIS 1, the SSTs in the postMBE simulations (corresponding to MIS 5, 7, 9 and 11) are 


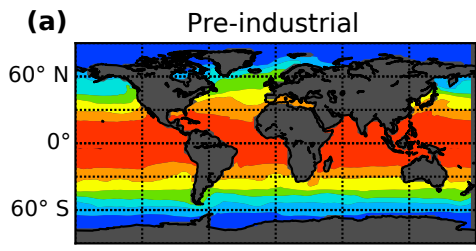

(b)

MIS1

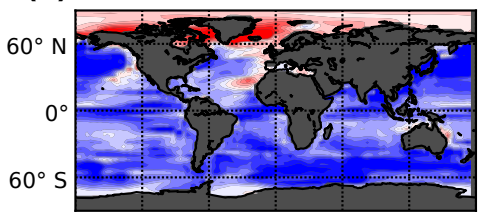

(e)

MIS9

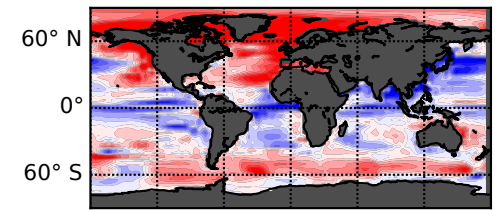

(h)

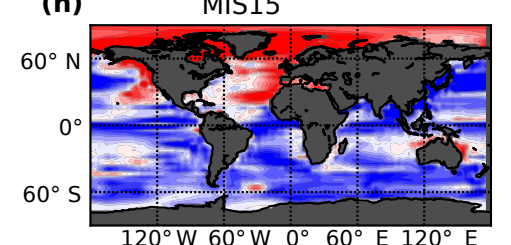

(c)
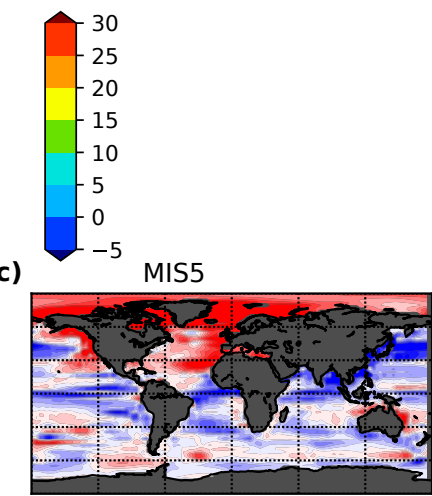

(f)

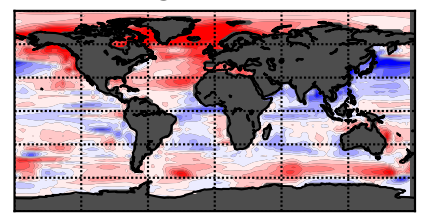

(i)

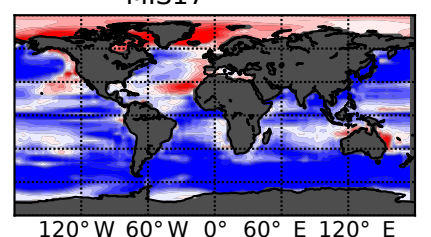

(d)

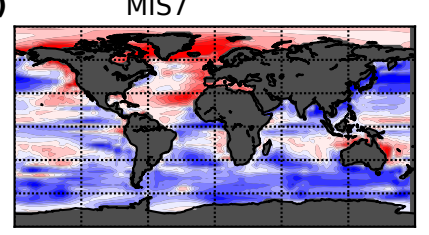

(g)

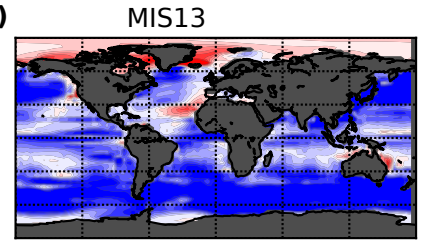

(j)

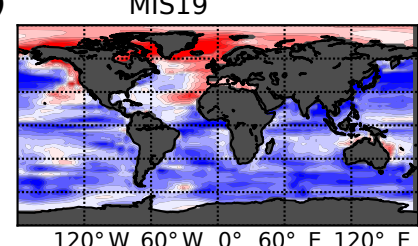

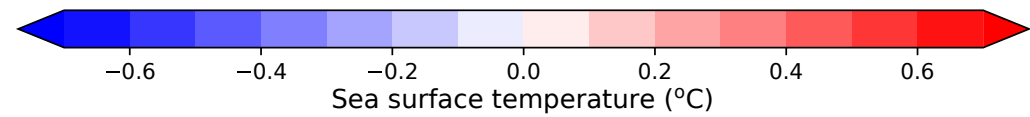

Figure 3. Annual SST $\left({ }^{\circ} \mathrm{C}\right)$ in (a) the pre-industrial control simulation and (b-j) the interglacial simulations of the OC series with fixed vegetation and fixed ice sheets, in anomalies with respect to the pre-industrial control simulation.

Table 3. SST data $\left({ }^{\circ} \mathrm{C}\right)$ from the Past Interglacials Working Group of PAGES (2016) and shown in Figs. $4 \mathrm{a}$ and b and 14.

\begin{tabular}{|c|c|c|c|c|c|c|c|c|c|c|c|c|c|}
\hline Latitude $\left({ }^{\circ}\right)$ & Longitude $\left({ }^{\circ}\right)$ & Site & MIS 5e & MIS 7e & MIS 9e & MIS $11 \mathrm{c}$ & MIS 13a & MIS $15 \mathrm{a}$ & MIS $17 \mathrm{c}$ & MIS $19 \mathrm{c}$ & post-MBE & pre-MBE & $\begin{array}{r}\text { Difference } \\
\text { pre- and post-MBE }\end{array}$ \\
\hline 57.51 & -15.85 & ODP 982 & 16.2 & 14.5 & 15.8 & 15 & 13.7 & 14.1 & 14.2 & 14.1 & 15.4 & 14.0 & -1.35 \\
\hline 56.04 & -23.23 & DSDP 552s & 15.1 & 14.7 & 14.2 & 16.4 & 12.4 & 14.7 & 18.3 & 14.7 & 15.1 & 15.0 & -0.08 \\
\hline 41.01 & -126.43 & ODP 1020 & 14.1 & 11.7 & 12.8 & 14 & 10.2 & 12.5 & 13.6 & 12.1 & 13.2 & 12.1 & -1.05 \\
\hline 41.00 & -32.96 & DSDP $607 \mathrm{~s}$ & 25.1 & 20.5 & 23.6 & 26.8 & 22.3 & 20.3 & 25.2 & 24 & 24 & 23.0 & -1.05 \\
\hline 32.28 & -1148.40 & ODP 1012 & 19.5 & 17.7 & 19.7 & 19.1 & 17.5 & 18.3 & 19.3 & 18 & 19 & 18.3 & -0.73 \\
\hline 19.46 & 116.27 & ODP 1146 & 27.3 & 26.3 & 27.3 & 26.8 & 26.1 & 26.3 & 26.9 & 26.2 & 27.0 & 26.4 & -0.55 \\
\hline 16.62 & 59.80 & ODP 722 & 27.7 & 27.3 & 27.5 & 27.5 & 27 & 27.1 & 27.2 & 27.2 & 27.5 & 27.1 & -0.38 \\
\hline 9.36 & 113.29 & ODP 1143 & 28.8 & 27.8 & 28.6 & 28.3 & 28.4 & 28.1 & 28.6 & 28.2 & 28.4 & 28.3 & -0.05 \\
\hline 2.04 & 141.76 & MD97-2140 & 29.5 & 28.6 & 29 & 29.5 & 28.6 & 28.4 & 29.3 & 28.9 & 29.2 & 28.8 & -0.35 \\
\hline 0.32 & 159.36 & ODP 806B & 29.6 & 29.2 & 28.8 & 30.2 & 28.2 & 29.4 & 29 & 29.4 & 29.5 & 29 & -0.45 \\
\hline-3.10 & -90.82 & ODP 846 & 25.1 & 24 & 23.8 & 24 & 23.6 & 23.7 & 23.7 & 23.7 & 24.2 & 23.7 & -0.55 \\
\hline-41.79 & -171.50 & ODP 1123 & 17.7 & 19 & 19.6 & 19.3 & 17.8 & 18.8 & 18 & 17.9 & 18.9 & 18.1 & -0.78 \\
\hline-42.91 & 8.9 & ODP 1090 & 17.1 & 10.2 & 14.7 & 13.9 & 10.2 & 11.7 & 11.1 & 10.4 & 14.0 & 10.9 & -3.125 \\
\hline-43.45 & 167.9 & MD06-2986 & 18 & 16.5 & 16.6 & 18.1 & 15.5 & 16.2 & 16.3 & 15.8 & 17.3 & 16.0 & -1.35 \\
\hline-45.52 & 174.95 & DSDP594 & 18.3 & 7.1 & 9.5 & 17.5 & 10 & 11.7 & 12.1 & 9.7 & 13.1 & 10.9 & -2.23 \\
\hline
\end{tabular}

also warmer than in the pre-industrial control in large areas in the Northern Hemisphere mid-latitudes. In the MIS 5, 9 and 11 simulations the SSTs are slightly warmer in the Southern Ocean. In the pre-MBE simulations (MIS 13, 15, 17 and $19)$, the ocean is mainly colder than the pre-industrial ocean, especially in the Southern Hemisphere. To compare the preMBE to post-MBE simulations, we built a composite (av- erage) for each period (pre- and post-MBE). We have excluded MIS 1 from the post-MBE composite, for which the date chosen corresponds to a $\mathrm{CO}_{2}$ much lower than the other post-MBE interglacials. We thus consider MIS 5, 7, 9 and 11 in the post-MBE composite and MIS 13, 15, 17 and 19 in the pre-MBE composite. The difference between the pre- and post-MBE composites shows colder SSTs in the pre-MBE 
OC: fixed vegetation, fixed ice sheets

(a)

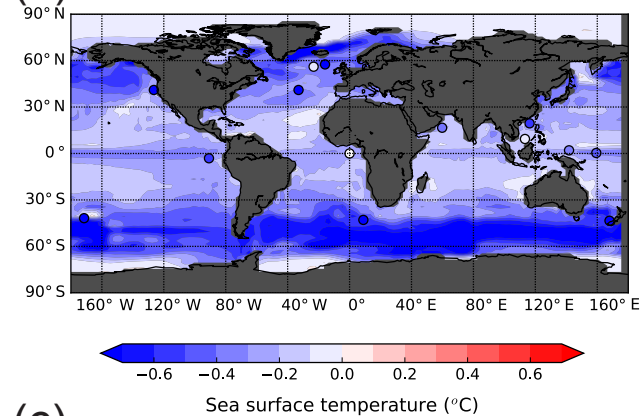

(c)

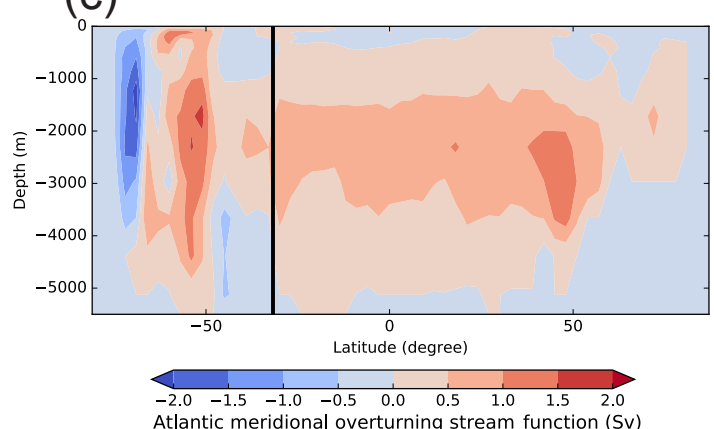

(e)

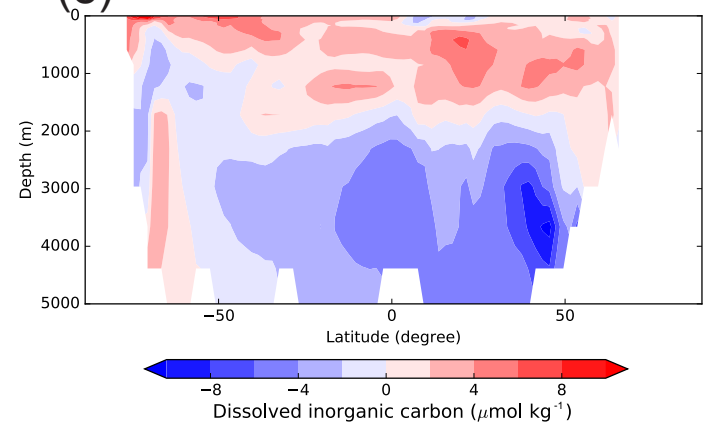

OVC: interactive vegetation, fixed ice sheets
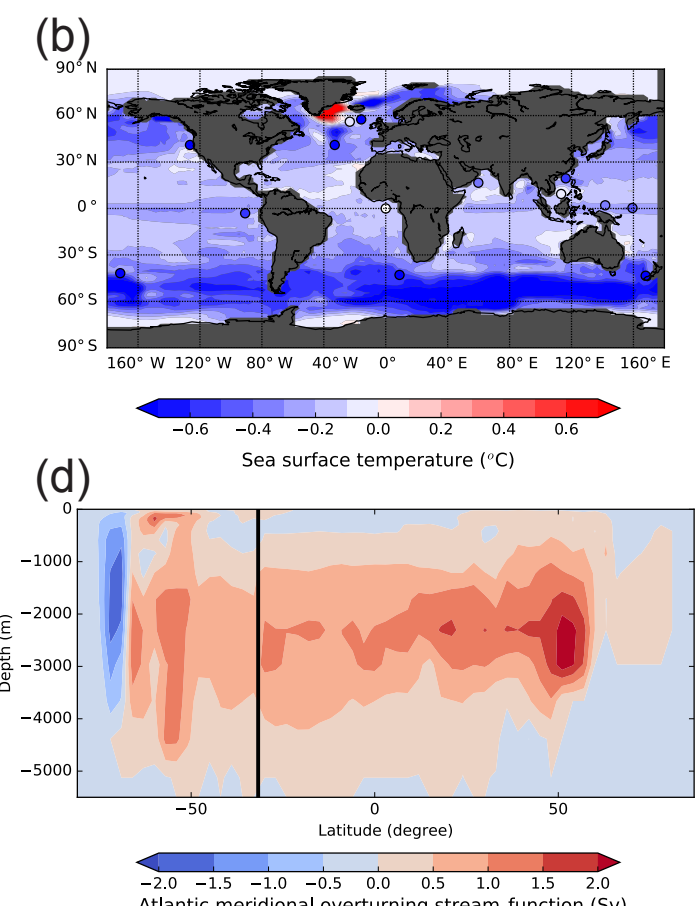

(f)

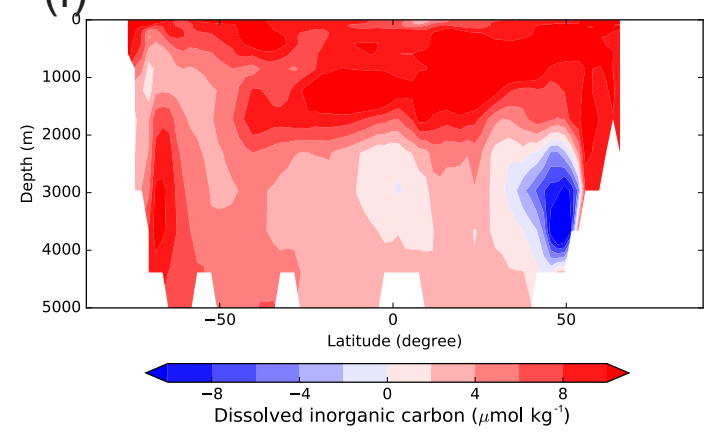

Figure 4. (a, b) Annual SST difference $\left({ }^{\circ} \mathrm{C}\right),(\mathbf{c}, \mathbf{d})$ meridional overturning circulation difference (Sv) and (e, f) dissolved inorganic carbon difference $(\mu \mathrm{mol} \mathrm{kg}-1)$ between pre-MBE (MIS 13, 15, 17, 19) and post-MBE (MIS 5, 7, 9, 11) interglacial simulations for (a, c, e) the OC series with fixed vegetation and fixed ice sheets and $(\mathbf{b}, \mathbf{d}, \mathbf{f})$ the OVC series with interactive vegetation and fixed ice sheets. The vertical black line indicates the limit between the Southern Ocean south of $32^{\circ} \mathrm{S}$ and the Atlantic Ocean north of $32^{\circ} \mathrm{S}$. The dots in panel (a) are SST data differences based on the Past Interglacials Working Group of PAGES (2016) (Table 3).

interglacial simulations compared to the post-MBE simulations, especially in the Southern Ocean (Fig. 4a). The difference in global mean simulated SST is $-0.30^{\circ} \mathrm{C}$, reaching up to $-0.36^{\circ} \mathrm{C}$ in the North Atlantic (between 30 and $65^{\circ} \mathrm{N}$ ) and $-0.43^{\circ} \mathrm{C}$ in the Southern Ocean (south of $54^{\circ} \mathrm{S}$ ). This is in general agreement with SST data, which indicate colder SSTs in the pre-MBE interglacial oceans, especially in the Southern Ocean (Table 3, Fig. 4a), although the comparison is limited by the lack of SST records across the MBE.

Compared to the pre-industrial period, the ventilation of the Southern Ocean is increased in all simulations (Fig. 5).
The formation of Antarctic Bottom Water (AABW) as well as the wind-driven meridional cell between 40 and $60^{\circ} \mathrm{S}$ (so-called Deacon cell) are both stronger. On average, the maximum of the Deacon cell is increased by $7 \%$ between pre- and post-MBE simulations, while AABW is increased by $18 \%$ (Fig. 4c). The meridional overturning circulation is also slightly increased by $6 \%$ and deepened in the Atlantic Ocean. All these results concerning oceanic circulation changes are very similar to those of Yin et al. (2013), allowing us to test their hypothesis on the impact of these 

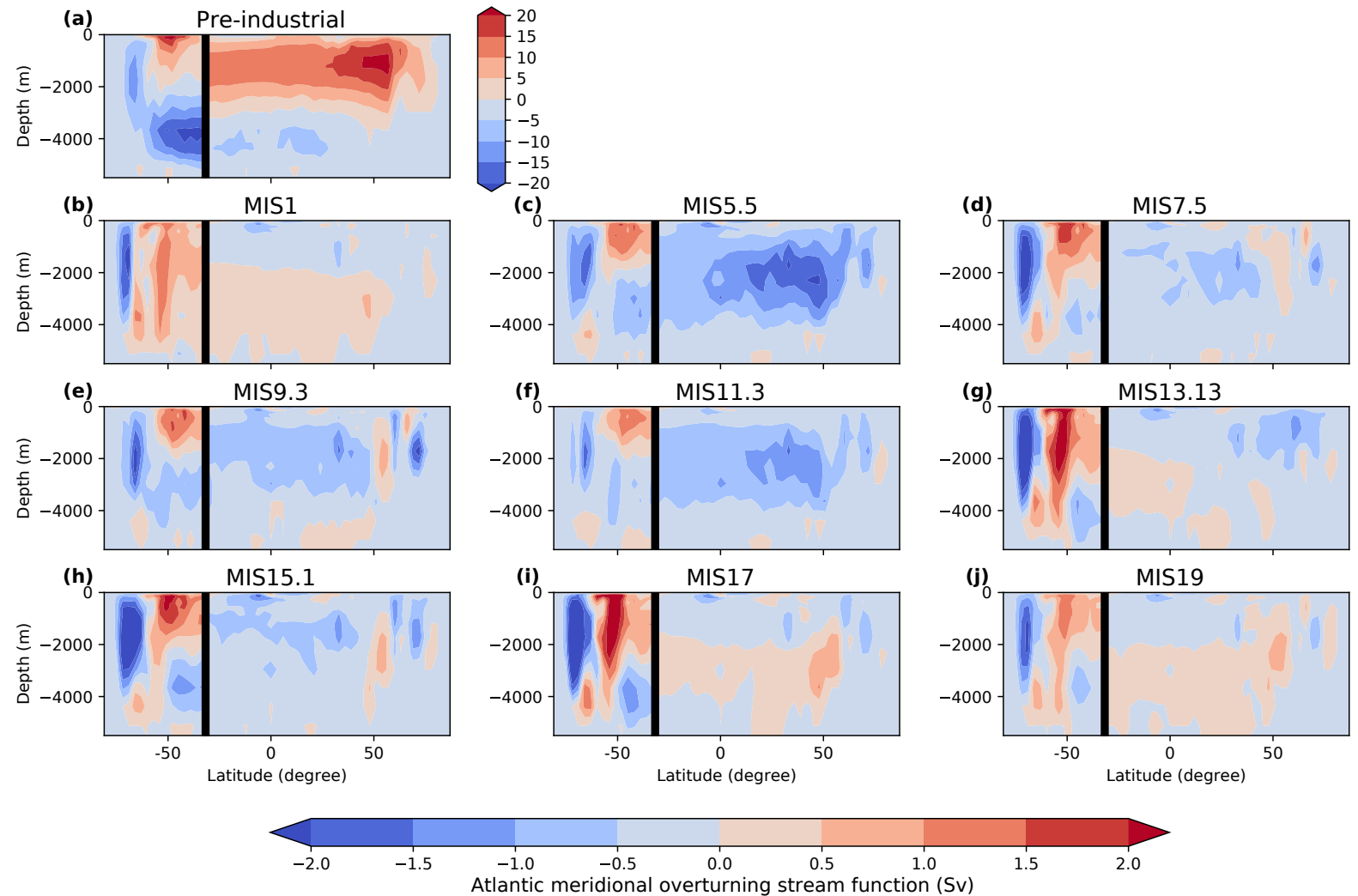

Figure 5. Meridional overturning circulation ( $\mathrm{Sv}$ ) in the Southern Ocean and in the Atlantic Ocean north of $32^{\circ} \mathrm{S}$ in (a) the pre-industrial control simulation and (b-j) the interglacial simulations of the OC series with fixed vegetation and fixed ice sheets, in anomalies with respect to the pre-industrial control simulation. The vertical black line indicates the limit between the Southern Ocean south of $32^{\circ} \mathrm{S}$ and the Atlantic Ocean north of $32^{\circ} \mathrm{S}$.

changes on ocean carbon uptake and atmospheric $\mathrm{CO}_{2}$ concentrations.

The changes in global ocean circulation and SST modify the carbon storage in the ocean. The colder SST, which increases dilution of $\mathrm{CO}_{2}$ at the ocean surface, associated with stronger ventilation in the pre-MBE simulations yields a larger carbon uptake by the ocean. Such processes result in higher dissolved inorganic carbon (DIC) concentrations in the Southern Ocean, as well as higher DIC concentration in the upper ocean (first $2 \mathrm{~km}$ of the ocean) (Fig. 4e), reflecting the average increase of $4.7 \mathrm{GtC}$ in pre-MBE simulations. Conversely, the DIC slightly decreases in the deeper ocean, which may be due to the increased ventilation of North Atlantic Deep Water bringing more carbon back from the deep ocean to the surface.

The stronger uptake of carbon by the ocean leads to a decrease in atmospheric $\mathrm{CO}_{2}$ concentration during the preMBE interglacials compared to the post-MBE ones (Fig. 6), in agreement with $\mathrm{CO}_{2}$ data as shown by the very good correlation between the measured and simulated values $(r=0.91$, $p<0.01$; Fig. 6). However, the difference in magnitude between pre- and post-MBE values is only a few parts per million in the simulations. Thus, even though simulations quali-

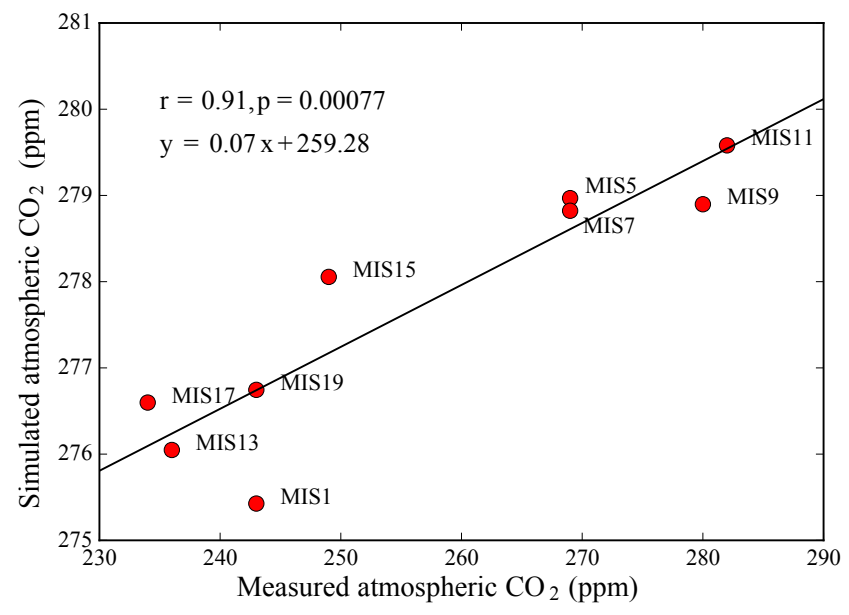

Figure 6. Simulated $\mathrm{CO}_{2}$ in the interglacial simulations of the $\mathrm{OC}$ series as a function of the measured $\mathrm{CO}_{2}$ from data (Lüthi et al., 2008). The Pearson correlation coefficient and the $p$ value are indicated at the top.

tatively reproduce the geological $\mathrm{CO}_{2}$ trend, with lower values during the pre-MBE than the post-MBE interglacials, 
the magnitude of the difference is much lower in the simulation $(\sim 1-5 \mathrm{ppm})$ than in the data $(\sim 30-40 \mathrm{ppm})$. In fact, the slope of the linear regression between simulated and observed atmospheric $\mathrm{CO}_{2}$ concentration is 0.07 , indicative of $\mathrm{a} \sim 14$-fold underestimation by the simulations.

Hence the ocean carbon uptake in the simulations is not sufficient to drive a significant lowering of atmospheric $\mathrm{CO}_{2}$. Either the change in global ocean circulation and SST should be larger or another mechanism and feedbacks need to be taken into account to modify the biological or physical carbon uptake and amplify the initial change. Since the representation of bottom water formation in the Southern Ocean is biased in the model, with an over-representation of open ocean convection, as is also the case for many more complex general circulation models (Heuzé et al., 2013), it is possible that this hinders simulating the full range of carbon storage due to ocean circulation changes, as it is suspected for colder periods such as the Last Glacial Maximum (around 21000 years ago) (Fischer et al., 2010).

\subsection{Role of land vegetation and soils (OVC simulations)}

In the first series of simulations, solely the ocean was allowed to respond to the different external forcings while land vegetation and soils were fixed to their pre-industrial distribution. To account for changes in land vegetation and soils on the carbon cycle, a second series of simulations (OVC) was conducted with an interactive terrestrial biosphere module on top of the ocean's module (Table 2).

Compared to the pre-industrial control simulation, more trees develop in North Africa and the southern part of Eurasia in these interglacial simulations, while the tree cover is reduced in central North America and some regions in the northern part of Eurasia (Fig. 7). When compared to OC simulations with fixed vegetation, the OVC simulations demonstrate a surface ocean warming almost everywhere except in the North Atlantic for some interglacials (Fig. 8). In response to the global warmer surface ocean, the stratification in the convection region in the North Atlantic increases (e.g. Swingedouw et al., 2007a) leading to a slowdown of the Atlantic meridional oceanic circulation, especially for MIS 1, 5 7, 9 and 15 (Fig. 9).

For the carbon cycle, the activation of the terrestrial module results in more carbon stored in land vegetation and soils for all interglacial simulations (Fig. 10b) since the vegetation cover increases compared to the control because of the warmer climate. This tends to lower atmospheric $\mathrm{CO}_{2}$ concentration, hence the $p \mathrm{CO}_{2}$ difference at the air-sea interface, leading to an outgassing of carbon from the ocean to the atmosphere, which ultimately decreases the storage of carbon in the ocean. The ocean carbon storage is also diminished compared to the series of simulations with fixed vegetation due to the warmer ocean temperature, which reduces the $\mathrm{CO}_{2}$ solubility in water. The increase in carbon storage in the terrestrial biosphere is generally larger than the loss of carbon from the ocean so that the carbon content of the atmosphere is also diminished in these simulations compared to the fixed vegetation simulations, and atmospheric $\mathrm{CO}_{2}$ is slightly lower or not changed (Fig. 11a).

In terms of difference between pre- and post-MBE interglacial simulations, we find less vegetation cover in most areas (except in North Africa and parts of south Eurasia) and consequently less carbon stored $(-48 \mathrm{GtC})$ in land vegetation and soils in the pre-MBE simulations compared to postMBE simulations (Fig. 12). This effect tends to increase atmospheric $\mathrm{CO}_{2}$ on average in pre-MBE interglacial simulations.

For the ocean, the differences between pre- and postMBE simulations are similar to the ones for the simulations with fixed vegetation (OC). On average, the SST is lower in the pre-MBE simulations compared to post-MBE simulations $\left(-0.28^{\circ} \mathrm{C}\right.$ globally, $-0.31^{\circ} \mathrm{C}$ in the North Atlantic and $-0.44^{\circ} \mathrm{C}$ in the Southern Ocean) except in a small area in the North Atlantic (Fig. 4b), and the ventilation is increased in the pre-MBE simulations (Fig. 4d). Hence the ocean can store more carbon in the pre-MBE simulations than the postMBE simulations with an average increase in carbon storage in the pre-MBE ocean of $43 \mathrm{GtC}$ compared to the post-MBE ocean. Similarly, the DIC concentration is higher in pre-MBE simulations, especially in the upper ocean and deep Southern Ocean, as in the previous series of simulations with fixed vegetation (Fig. 4f).

As the diminution in land carbon storage is larger than the increase in ocean carbon storage, more carbon is conserved in the atmosphere resulting in higher $\mathrm{CO}_{2}$ on average for the pre-MBE simulations than the post-MBE simulations (Fig. 11b). There is thus a qualitative disagreement (negative correlation of $-0.33(p=0.38)$ between simulated and observed atmospheric $\mathrm{CO}_{2}$ for the interglacials considered) with the observations.

Nevertheless, it should be noted that permafrost (frozen soil) was not taken into account in these simulations. If there was more permafrost during the colder pre-MBE interglacials, it could store more carbon on land and counteract the loss of carbon due to the reduction of vegetation cover and production (Crichton et al., 2016).

Comparison with pollen data (Table 4) indicates that the model is in qualitative agreement with reconstructed tree cover change in South America where the tree cover was smaller on average in pre-MBE than in post-MBE interglacials (Fig. 12a). In southern Europe, the tree fraction data indicate that on average slightly more tree cover prevailed during pre-MBE than during post-MBE interglacials, also in agreement with simulations, although the variability in the data among interglacials is large.

\subsection{Impact of different ice sheets (OVIC simulations)}

The last series of simulations (OVIC) has the same design as OVC but also takes into account possible differences in ice 

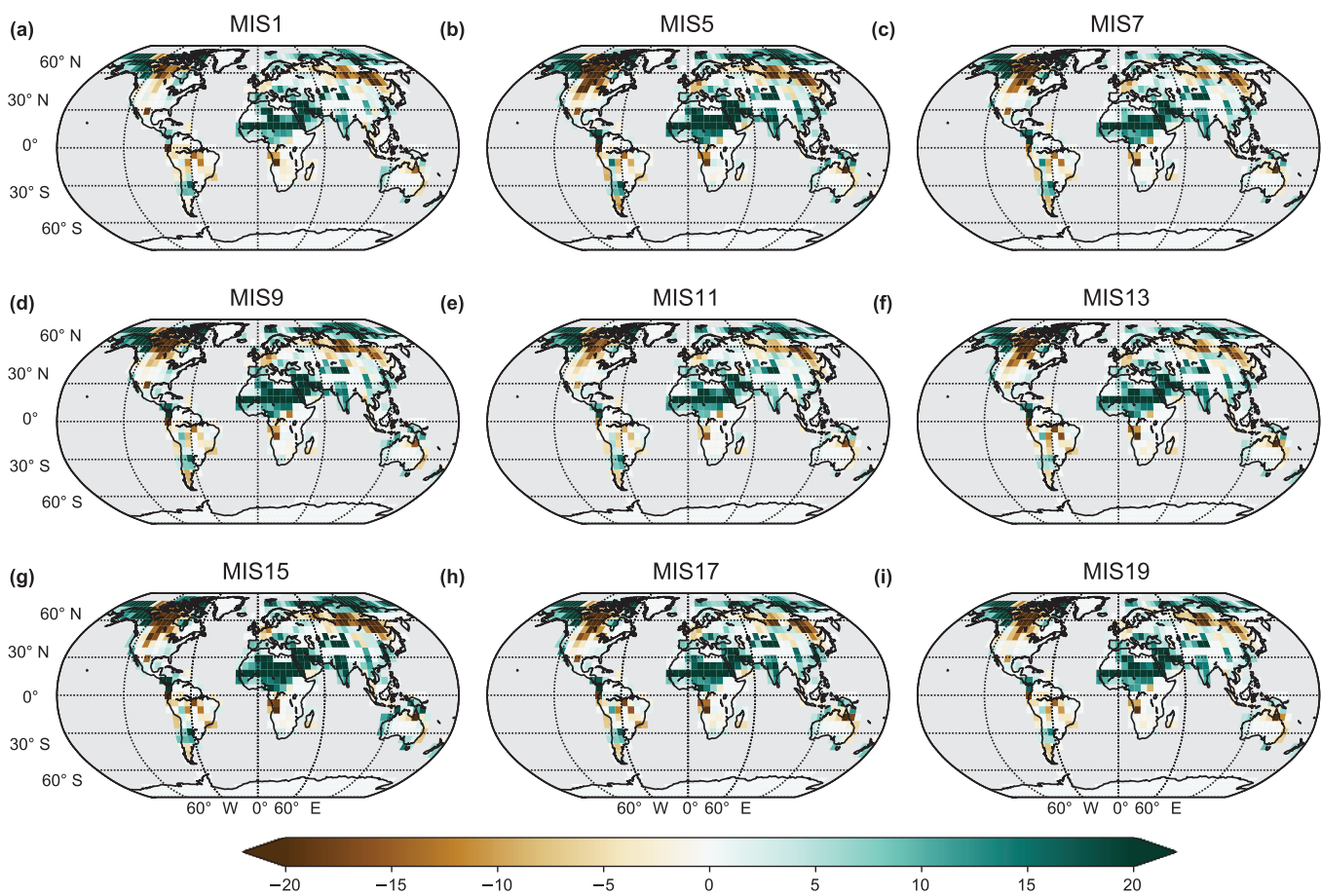

$\begin{array}{lllll}-20 & -15 & -10 & -5 & 0 \\ & & & & \text { Tree cover }(\%)\end{array}$

Figure 7. Tree cover $(\%)$ change with respect to the pre-industrial control simulation for the OVC series with interactive vegetation and fixed ice sheets.
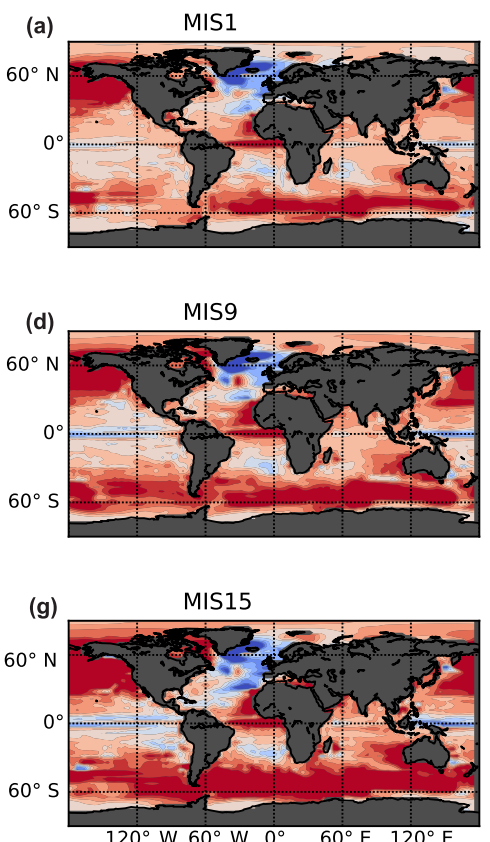

(b)

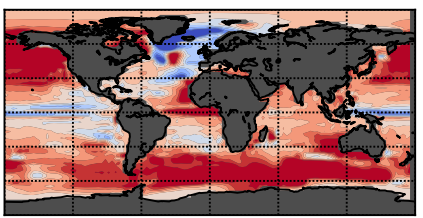

(e)

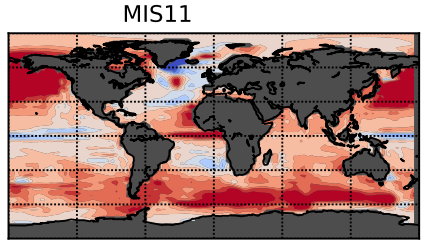

(h)

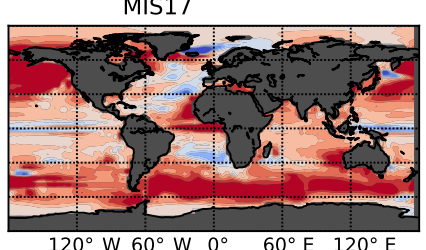

(c)

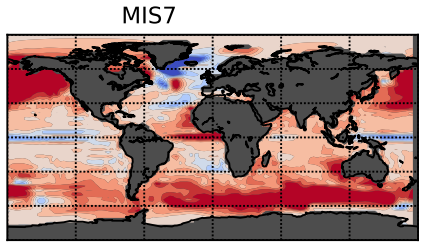

(f)

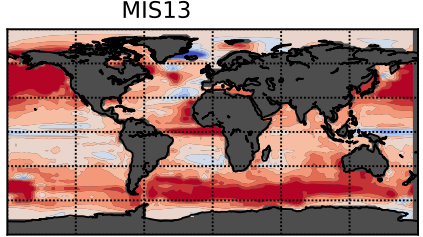

(i)

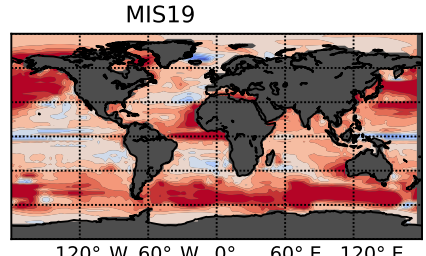

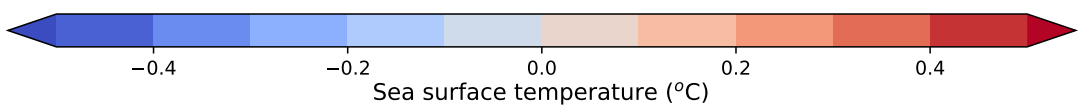

Figure 8. Annual SST difference $\left({ }^{\circ} \mathrm{C}\right)$ between simulations with interactive vegetation (OVC) and with fixed vegetation (OC). 

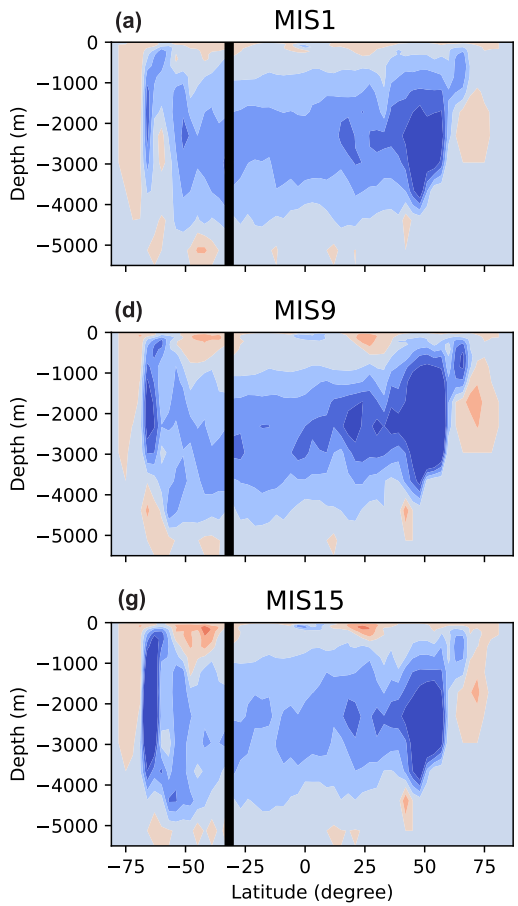
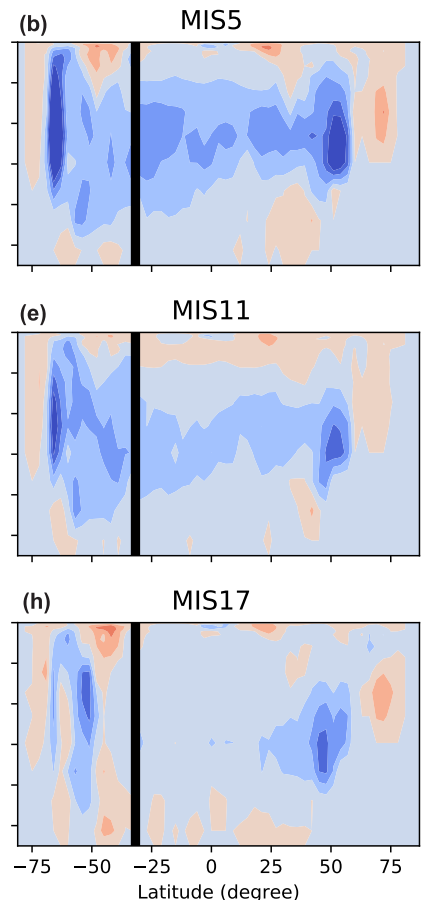
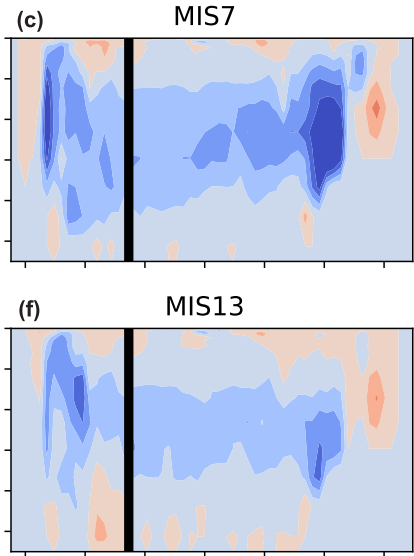

(i)

MIS19

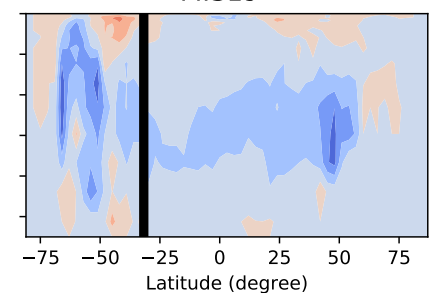

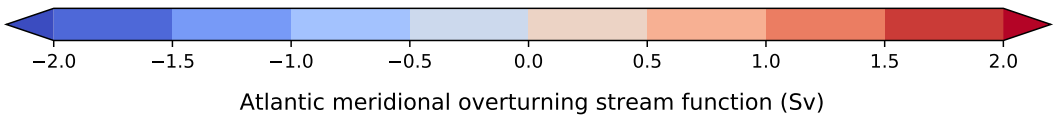

Figure 9. Meridional overturning circulation difference (Sv) between simulations with interactive vegetation (OVC) and with fixed vegetation (OC). The vertical black line indicates the limit between the Southern Ocean south of $32^{\circ} \mathrm{S}$ and the Atlantic Ocean north of $32^{\circ} \mathrm{S}$.
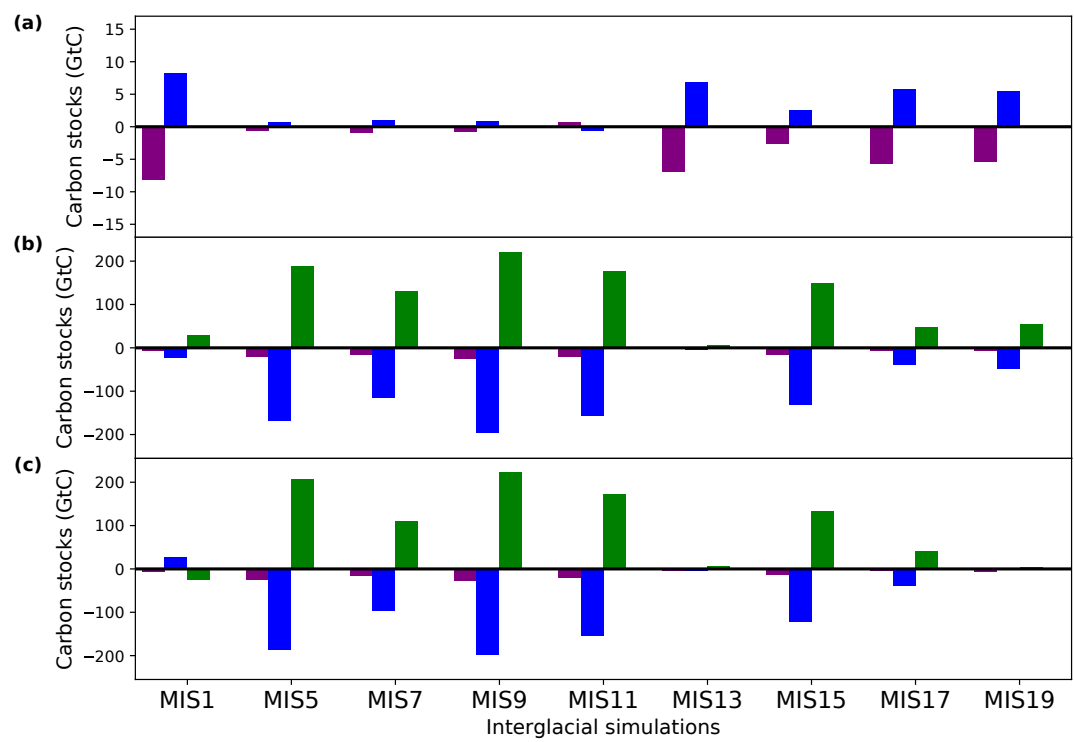

Figure 10. Carbon stocks (Gt C) in the three reservoirs (atmosphere, ocean and land) for each simulation. (a) OC series with fixed vegetation and fixed ice sheets, (b) OVC series with interactive vegetation and fixed ice sheets, and (c) OVIC series with interactive vegetation and different prescribed ice sheets. The stocks are given as anomalies with respect to the control pre-industrial simulation.

sheet distribution in the Northern Hemisphere based on numerical simulations (Ganopolski and Calov, 2011). The sim- ulated ice sheet distributions used for our interglacial simulations mainly differ in North America. On average, the North 

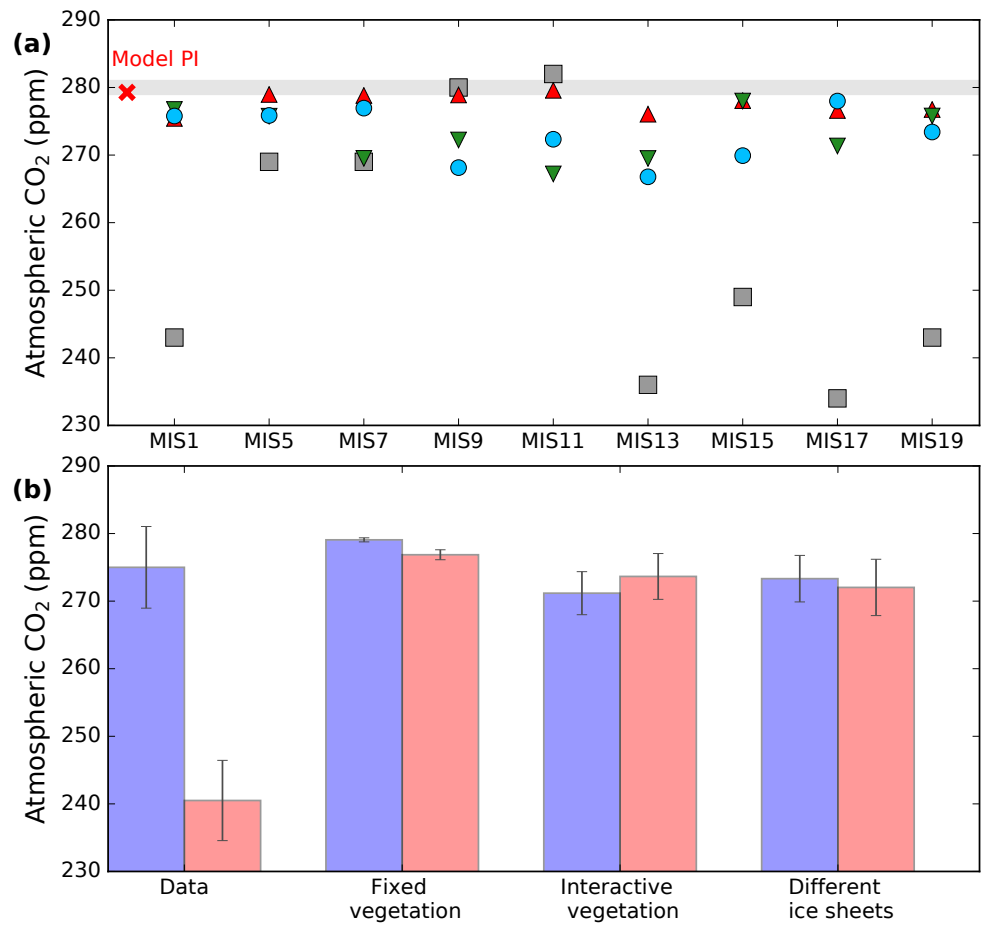

Post-MBE (MIS 5, 7, 9, 11) Pre-MBE (MIS 13, 15, 17, 19)

Figure 11. (a) $\mathrm{CO}_{2}$ concentration (ppm) at the end of the simulations and (b) composite (average) $\mathrm{CO}_{2}$ (ppm) in the pre-MBE (MIS 13, 15, 17, 19) and post-MBE (MIS 5, 7, 9, 11) interglacial simulations.
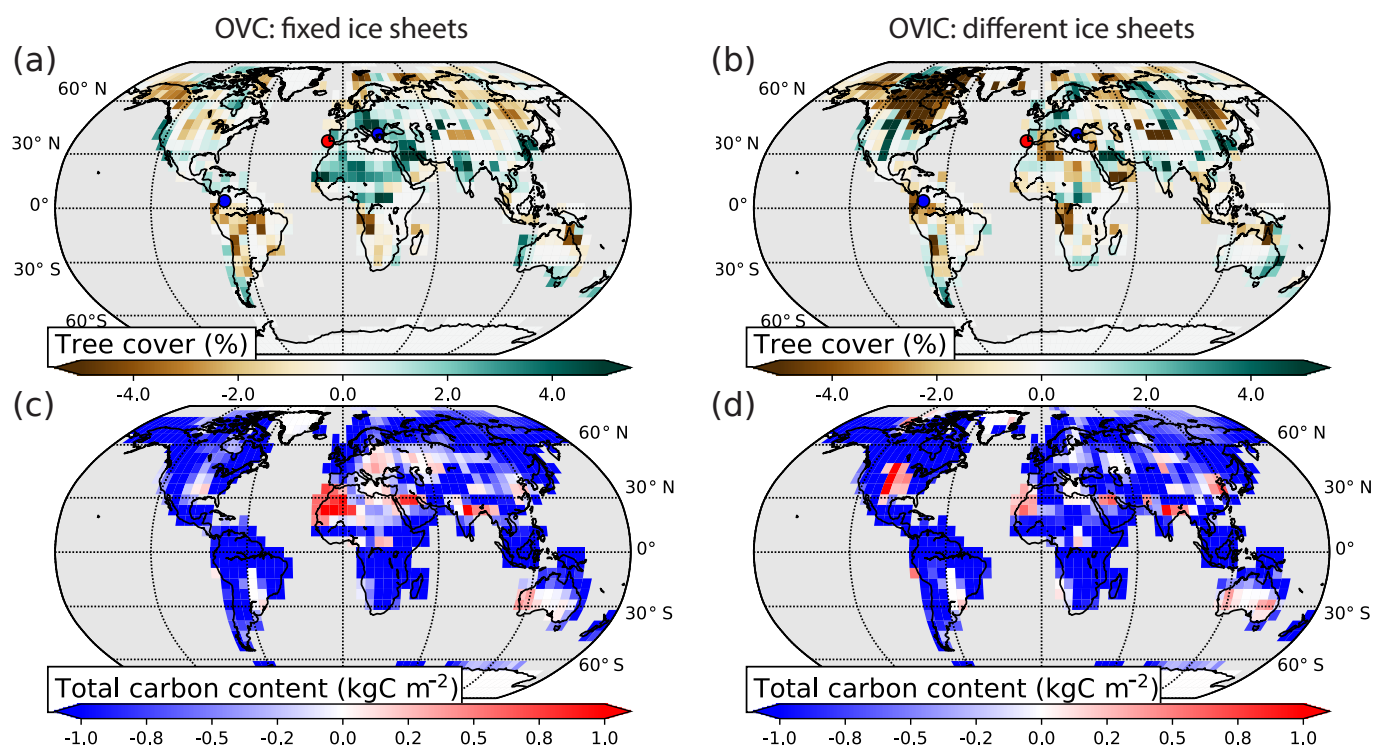

Figure 12. (a, b) Tree cover $(\%)$ and $(\mathbf{c}, \mathbf{d})$ carbon storage $\left(\mathrm{kgCm}^{-2}\right)$ difference between pre-MBE (MIS 13, 15, 17, 19) and post-MBE (MIS 5, 7, 9, 11) interglacial simulations for (a,c) the OVC series with interactive vegetation and fixed ice sheets and (b,d) the OVIC series with interactive vegetation and different ice sheets. Qualitative indication of tree cover change from data is indicated with dots: blue indicates a reduction of tree cover on average during pre-MBE interglacials compared to post-MBE interglacials, and red indicates an increase.

American ice sheet is more extended in the pre-MBE interglacials compared to the post-MBE interglacials (Fig. 13).
The change of ice sheet extent has a large regional impact on vegetation cover, which is reduced where the ice sheet extends more. On average, it results in a reduction of vege- 
Table 4. Tree cover (\%) reconstructed from pollen data at three sites. SW Iberian margin: MIS 5 (MD95-2042, Sanchez Goñi et al., 1999), MIS 7 (MD01-2443; Roucoux et al., 2006), MIS 9, 13, 15, 17 (IODP 1385, unpublished data), MIS 11 (U1385, Oliveira et al., 2016), MIS 19 (U1385, Sanchez Goñi et al., 2016); Tenaghi Philippon, Greece (Past Interglacials Working Group of PAGES, 2016); and Funza, Colombia (Past Interglacials Working Group of PAGES, 2016).

\begin{tabular}{|c|c|c|c|c|c|c|c|}
\hline & & \multicolumn{2}{|c|}{$\begin{array}{l}\text { SW Iberian margin } \\
\text { (MD95-2042, MD01-2443, } \\
\text { IODP U1385) Tree cover: } \\
\text { Mediterranean forest pollen \% }\end{array}$} & \multicolumn{2}{|c|}{$\begin{array}{l}\text { Tenaghi Philippon } \\
\text { Tree cover: temperate forest } \\
\text { pollen } \%\end{array}$} & \multicolumn{2}{|c|}{$\begin{array}{l}\text { Funza } \\
\text { Arboreal pollen } \% \text {-Quercus } \%\end{array}$} \\
\hline & & Interglacial values & Average & Interglacial values & average & Interglacial values & average \\
\hline \multirow[t]{4}{*}{ Post-MBE } & MIS5e & 68 & \multirow[t]{4}{*}{53.0} & 96 & \multirow[t]{4}{*}{95.9} & 86 & \multirow[t]{4}{*}{76.7} \\
\hline & MIS7e & 42 & & 92.4 & & 75 & \\
\hline & MIS9c & 54 & & 95.5 & & 73 & \\
\hline & MIS11c & 48 & & 99.5 & & 73 & \\
\hline \multirow[t]{4}{*}{ Pre-MBE } & MIS13a & 48 & \multirow[t]{4}{*}{57} & 95.8 & \multirow[t]{4}{*}{89.5} & 73 & \multirow[t]{4}{*}{71.2} \\
\hline & MIS15a & 54 & & 96.9 & & 65 & \\
\hline & MIS17c & 78 & & 82.2 & & 78 & \\
\hline & MIS19c & 47 & & 83.3 & & 69 & \\
\hline \multicolumn{2}{|c|}{$\begin{array}{l}\text { Difference pre-MBE - } \\
\text { post-MBE }\end{array}$} & & 4 & \multicolumn{2}{|r|}{-6.4} & & -5.5 \\
\hline
\end{tabular}

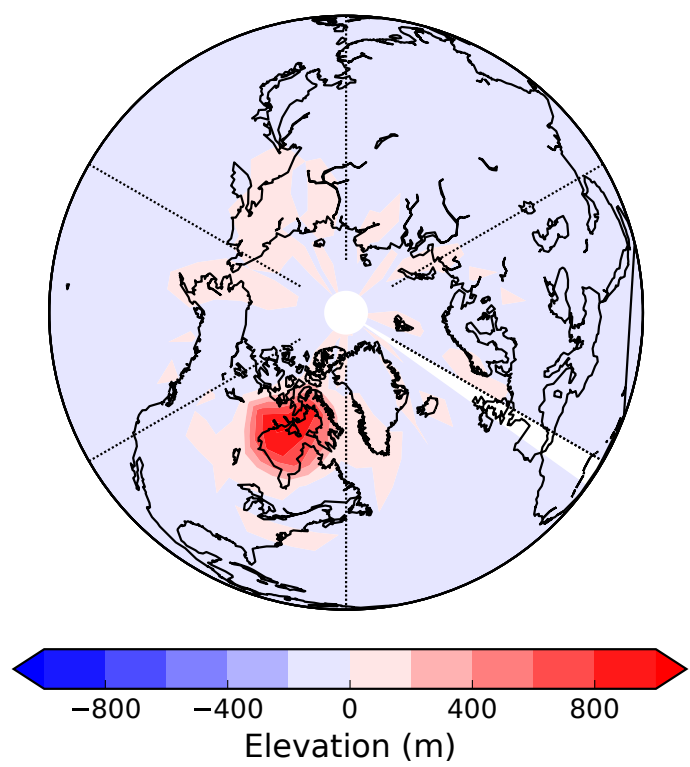

Figure 13. Ice sheet elevation difference $(\mathrm{m})$ between the average of the pre-MBE (MIS 13, 15, 17, 19) and post-MBE (MIS 5, 7, 9, 11) interglacial simulations.

tation in North America in the pre-MBE interglacials, when the ice sheet is more extended, compared to the post-MBE interglacials (Fig. 12b and d).

The increase in ice sheet extent and diminution of vegetation cover for pre-MBE simulations has two main impacts for the carbon cycle: (i) it diminishes the terrestrial biosphere carbon storage, increasing atmospheric $\mathrm{CO}_{2}$ and (ii) it also cools global climate due to the high ice albedo. The SST also decreases by $0.32{ }^{\circ} \mathrm{C}$ on the global scale. Sea surface temperature changes are especially pronounced in polar zones, with a drop of $0.49^{\circ} \mathrm{C}$ in the North Atlantic and $0.47^{\circ} \mathrm{C}$ in the Southern Ocean (Fig. 14 compared to Fig. 4b). Consequently, the ocean carbon storage increases, which lowers atmospheric $\mathrm{CO}_{2}$. This second effect dominates and the overall result is lower atmospheric $\mathrm{CO}_{2}$ concentration in pre-MBE simulations compared to post-MBE simulations (Fig. 11). As for the other processes analysed, they only modifies atmospheric $\mathrm{CO}_{2}$ by a few parts per million, though correcting back (compared to OVC simulations) the difference preMBE minus post-MBE towards the observations. Nevertheless, the correlation between simulated and measured $\mathrm{CO}_{2}$ (accounting for MIS1) is very small $(-0.08)$ and not significant $(p=0.83)$. The magnitude of the changes of atmospheric $\mathrm{CO}_{2}$ among the different interglacials is once again largely underestimated as compared to observations.

Accounting for different ice sheets in the OVIC series seems to improve the model-data comparison in southern Europe for tree cover (Fig. 12b) where the data are at the limit between regions of more tree coverage and less tree coverage in the model. This highlights the role of ice sheet extent in setting the vegetation pattern. Nevertheless, the uncertainty in ice sheet distribution is very large and the model-based reconstruction might not be accurate. For example, the lack of ice-rafted debris from North America before MIS16 and the presence of ice-rafted debris from Europe indicate that the ice sheet over Europe (Hoddell et al., 2008) could have been more extended and the Laurentide ice sheets in North America were not. In addition, the model-based reconstruction that we used shows relatively small changes of sea level equivalent between interglacials. Data reconstructions seem to indi- 


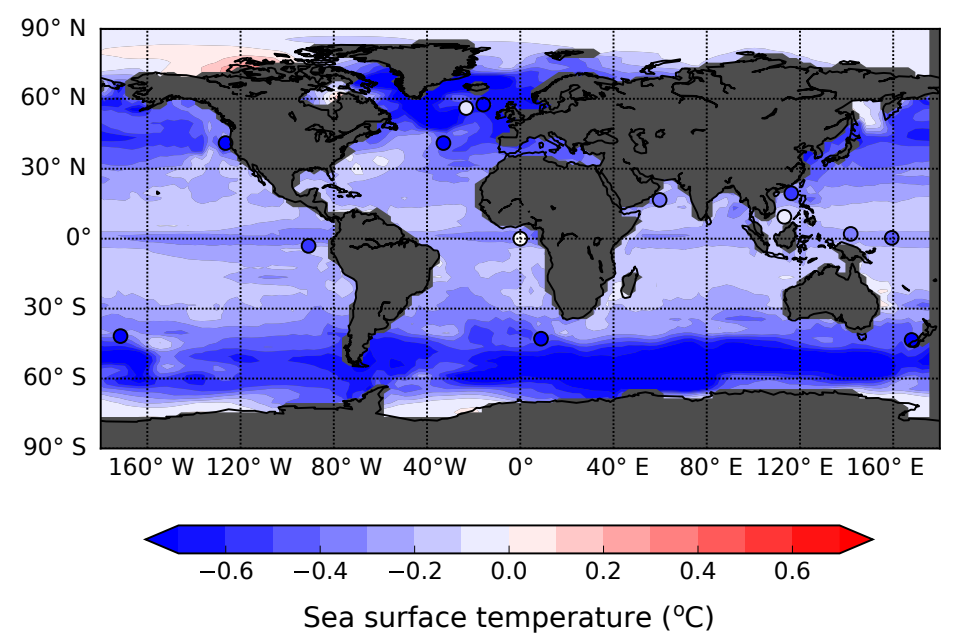

Figure 14. Annual sea surface temperature difference $\left({ }^{\circ} \mathrm{C}\right)$ between the average of the pre-MBE (MIS $\left.13,15,17,19\right)$ and post-MBE (MIS 5, $7,9,11)$ interglacials with interactive vegetation and different ice sheets (OVIC). The vertical black line indicates the limit between the Southern Ocean south of $32^{\circ} \mathrm{S}$ and the Atlantic Ocean north of $32^{\circ} \mathrm{S}$. The dots are SST data differences based on the Past Interglacials Working Group of PAGES (2016) (Table 3).

cate possible larger differences between interglacials (Spratt and Lisiecki, 2016), whose effect on the size of the land surface and the carbon cycle remains to be tested. Sensitivity experiments with prescribed idealised ice sheets designed to be very different would help to evaluate their impact.

\section{Conclusions}

Using a fully coupled climate model of intermediate complexity including an interactive carbon cycle, we have shown that the difference between pre-MBE and post-MBE cannot be explained by the simulated changes in ocean and vegetation induced by orbital and greenhouse gases forcing. While the oceanic response alone is in qualitative agreement with data (sign of the changes, correlation between each interglacial), it largely underestimates the amplitude of the changes. Past work suggested that either a vigorous AABW (Yin, 2013) or weak Atlantic thermohaline circulation (Köhler and Fischer, 2006) during pre-MBE interglacials could increase the oceanic carbon storage and explain the lower $\mathrm{CO}_{2}$ than during post-MBE interglacials. Other studies for different background climates have shown opposite results with respect to the effect of ocean circulation on carbon storage. A weaker Atlantic meridional oceanic circulation could either result in more ocean carbon storage with a pre-industrial climate (Obata, 2007; Menviel et al., 2008; Bozbiyik et al., 2011) or glacial climate (Menviel et al., 2008), or it could yield less ocean carbon storage with a pre-industrial climate (Marchal et al., 1998; Swingedouw et al., 2007b; Bouttes et al., 2012) or a glacial climate (Schmittner and Galbraith, 2008; Bouttes et al., 2012; Schmittner and Lund, 2015). Menviel et al. (2014) showed that on top of changes in North Atlantic Deep Water formation, modifications of AABW and
North Pacific Deep Water (NPDW) formations could results in different oceanic carbon storage. Data indicate that the modern reduction of carbon uptake in the North Atlantic is due to a reduction in the overturning circulation (Perez et al., 2013). Because the atmospheric $\mathrm{CO}_{2}$ change that we simulate has a low magnitude of only a few parts per million, it is not yet possible to infer whether stronger or weaker overturning during pre-MBE interglacials could have significantly lowered atmospheric $\mathrm{CO}_{2}$.

Furthermore, accounting for the vegetation response complicates the simulated response and entirely removes the qualitative agreement. The vegetation response depends on ice sheet extent, and accounting for ice sheet variations limits the disagreement. Comparison of simulated vegetation changes with available pollen data indicates partial agreement, underlying the need to improve vegetation simulations and increase the data coverage to more precisely constrain the change of vegetation cover. The vegetation model in iLOVECLIM only simulates grass and trees; to better evaluate the different vegetation responses to orbital and $\mathrm{CO}_{2}$ forcings it would be useful to use a more complex terrestrial biosphere model.

We argue that additional processes need to be accounted for or should be better represented in climate models to explain the observations. It is possible that either many different processes, some of them not included in the present model, lead to the observed atmospheric $\mathrm{CO}_{2}$ concentration or that just a first-order process is misrepresented or not included. In particular, the storage of carbon in frozen soils (permafrost) should be included in future modelling work. Response of the Southern Ocean, the widest oceanic region with large airsea fluxes of $\mathrm{CO}_{2}$, is also a good candidate, given the known deficiency in coarse-resolution climate models for the repre- 
sentation of the key element of its dynamics (eddies, katabatic winds, AABW formation, brines, etc.). The impact of ventilation changes could be tested by artificially modifying the buoyancy forcing in the areas of bottom water formation. The use of higher-resolution models in this region could help to better evaluate its response to different interglacial conditions.

Data availability. The model output data is provided in the Supplement.

Supplement. The supplement related to this article is available online at: https://doi.org/10.5194/cp-14-239-2018-supplement.

Competing interests. The authors declare that they have no conflict of interest.

Acknowledgements. We are grateful to the two anonymous reviewers for their useful comments. The research leading to these results has received funding from the European Union's Horizon 2020 research and innovation programme under grant agreement no. 656625 , project "CHOCOLATE". We also acknowledge WarmClim, a LEFE-INSU IMAGO project. All the simulations have been performed on the Avakas computer cluster from the Mésocentre de Calcul Intensif Aquitain (MCIA). We thank Vincent Marieu for his assistance in setting up the model on this supercomputer. Discussions with Anne-Sophie Kremer and Thibaut Caley were useful to develop this paper and are acknowledged.

Edited by: Arne Winguth

Reviewed by: two anonymous referees

\section{References}

Bereiter, B., Eggleston, S., Schmitt, J., Nehrbass-Ahles, C., Stocker, T. F., Fischer, H., Kipfstuhl, S., and Chappellaz, J.: Revision of the EPICA Dome $\mathrm{C} \mathrm{CO}_{2}$ record from 800 to $600 \mathrm{kyr}$ before present, Geophys. Res. Lett., 42, 542-549, https://doi.org/10.1002/2014GL061957, 2015.

Berger A.: Long-term variations of daily insolation and quaternary climatic changes, J. Atmos. Sci., 35, 2362-2367, 1978.

Bouttes, N., Roche, D. M., and Paillard, D.: Systematic study of the impact of fresh water fluxes on the glacial carbon cycle, Clim. Past, 8, 589-607, https://doi.org/10.5194/cp-8-589-2012, 2012.

Bouttes, N., Roche, D. M., Mariotti, V., and Bopp, L.: Including an ocean carbon cycle model into $i$ LOVECLIM (v1.0), Geosci. Model Dev., 8, 1563-1576, https://doi.org/10.5194/gmd-8-15632015, 2015.

Bozbiyik, A., Steinacher, M., Joos, F., Stocker, T. F., and Menviel, L.: Fingerprints of changes in the terrestrial carbon cycle in response to large reorganizations in ocean circulation, Clim. Past, 7, 319-338, https://doi.org/10.5194/cp-7-319-2011, 2011.
Brovkin, V., Ganopolski, A., and Svirezhev, Y.: A continuous climate-vegetation classification for use in climate-biosphere studies, Ecol. Model., 101, 251-261, 1997.

Brovkin, V., Bendtsen, J., Claussen, M., Ganopolski, A., Kubatzki, C., Petoukhov, V., and Andreev, A.: Carbon cycle, vegetation and climate dynamics in the Holocene: experiments with the CLIMBER-2 model, Global Biogeochem. Cyc., 16, 1139, https://doi.org/10.1029/2001GB001662, 2002.

Calov, R., Ganopolski, A., Claussen, M., Petoukhov, V., and Greve. R.: Transient simulation of the last glacial inception, Part I: Glacial inception as a bifurcation of the climate system, Clim. Dynam., 24, 545-561, https://doi.org/10.1007/s00382005-0007-6, 2005.

Crichton, K. A., Bouttes, N., Roche, D. M., Chappellaz, J., and Krinner, G.: Permafrost carbon as a missing link to explain $\mathrm{CO}_{2}$ changes during the last deglaciation, Nat. Geosci., 9, 683-686, https://doi.org/10.1038/ngeo2793, 2016.

Fischer, H., Schmitt, J., Lüthi, D., Stocker, T. F., Tschumi, T., Parekh, P., Joos, F., Köhler, P., Völker, C., Gersonde, R., Barbante, C., Le Floch, M., Raynaud, D., and Wolff, E.: The role of Southern Ocean processes on orbital and millennial $\mathrm{CO}_{2}$ variations - a synthesis, Quaternary Sci. Rev., 29, 193-205, https://doi.org/10.1016/j.quascirev.2009.06.007, 2010.

Ganopolski, A. and Calov, R.: The role of orbital forcing, carbon dioxide and regolith in $100 \mathrm{kyr}$ glacial cycles, Clim. Past, 7, 1415-1425, https://doi.org/10.5194/cp-7-1415-2011, 2011.

Ganopolski, A., Petoukhov, V., Rahmstorf, S., Brovkin, V., Claussen, M., Eliseev, A., and Kubatzki, C.: CLIMBER-2: a climate system model of intermediate complexity, Part II: Model sensitivity, Clim. Dynam., 17, 735-751, 2001.

Goosse, H., Brovkin, V., Fichefet, T., Haarsma, R., Huybrechts, P., Jongma, J., Mouchet, A., Selten, F., Barriat, P.-Y., Campin, J.M., Deleersnijder, E., Driesschaert, E., Goelzer, H., Janssens, I., Loutre, M.-F., Morales Maqueda, M. A., Opsteegh, T., Mathieu, P.-P., Munhoven, G., Pettersson, E. J., Renssen, H., Roche, D. M., Schaeffer, M., Tartinville, B., Timmermann, A., and Weber, S. L.: Description of the Earth system model of intermediate complexity LOVECLIM version 1.2, Geosci. Model Dev., 3, 603-633, https://doi.org/10.5194/gmd-3-6032010, 2010.

Greve, R.: A continuum-mechanical formulation for shallow polythermal ice sheets, Philos. T. R. Soc. Lond., 355, 921-974, 1997.

Heuzé, C., Heywood, K. J., Stevens, D. P., and Ridley, J. K.: Southern Ocean bottom water characteristics in CMIP5 models, Geophys. Res. Lett., 40, 1409-1414, https://doi.org/10.1002/grl.50287, 2013.

Hodell, D. A., Channell, J. E. T., Curtis, J. H., Romero, O. E., and Röhl, U.: Onset of "Hudson Strait" Heinrich events in the eastern North Atlantic at the end of the middle Pleistocene transition $(\sim 640 \mathrm{ka})$ ?, Paleoceanography, 23, PA4218, https://doi.org/10.1029/2008PA001591, 2008.

Köhler, P. and Fischer, H.: Simulating low frequency changes in atmospheric $\mathrm{CO}_{2}$ during the last 740000 years, Clim. Past, 2, 57-78, https://doi.org/10.5194/cp-2-57-2006, 2006.

Lang, N. and Wolff, E. W.: Interglacial and glacial variability from the last $800 \mathrm{ka}$ in marine, ice and terrestrial archives, Clim. Past, 7, 361-380, https://doi.org/10.5194/cp-7-361-2011, 2011. 
Lisiecki, L. E. and Raymo, M. E.: A Pliocene-Pleistocene stack of 57 globally distributed benthic $\delta^{18} \mathrm{O}$ records, Paleoceanography, 20, PA1003, https://doi.org/10.1029/2004PA001071, 2005.

Lüthi, D., Le Floch, M., Bereiter, B., Blunier, T., Barnola, J.-M., Siegenthaler, U., Raynaud, D., Jouzel, J., Fischer, H., Kawamura, K., and Stocker, T. F.: High-resolution carbon dioxide concentration record 650,000-800,000 years before present, Nature, 453, 379-382, https://doi.org/10.1038/nature06949, 2008.

Marchal, O., Stocker, T. F., and Joos, F.: Impact of oceanic reorganizations on the ocean carbon cycle and atmospheric carbon dioxide content, Paleoceanography, 13, 225-244, 1998.

Menviel, L., Timmermann, A., Mouchet, A., and Timm, O.: Meridional reorganizations of marine and terrestrial productivity during Heinrich events, Paleoceanography, 23, PA1203, https://doi.org/10.1029/2007PA001445, 2008.

Menviel, L., England, M. H., Meissner, K., Mouchet, A., and Yu, J.: Atlantic-Pacific seesaw and its role in outgassing $\mathrm{CO}_{2}$ during Heinrich events, Paleoceanography, 29, 58-70, https://doi.org/10.1002/2013PA002542, 2014.

Obata, A.: Climate-carbon cycle model response to freshwater discharge into the North Atlantic, J. Climate, 20, 5962-5976, https://doi.org/10.1175/2007JCLI1808.1, 2007.

Oliveira, D., Desprat, S., Rodrigues, T., Naughton, F., Hodell, D., Trigo, R., Rufino, M., Lopes, C., Abrantes, F., and Sánchez Goñi, M. F.: The complexity of millennial-scale variability in southwestern Europe during MIS 11, Quaternary Res., 86, 373 387, https://doi.org/10.1016/j.yqres.2016.09.002, 2016.

Past Interglacials Working Group of PAGES: Interglacials of the last 800,000 years, Rev. Geophys., 54, 162-219, https://doi.org/10.1002/2015RG000482, 2016.

Pérez, F. F., Mercier, H., Vázquez-Rodríguez, M., Lherminier, P., Velo, A., Pardo, P. C., Rosón, G., and Ríos, A. F.: Atlantic Ocean $\mathrm{CO}_{2}$ uptake reduced by weakening of the meridional overturning circulation, Nat. Geosci., 6, 146-152, https://doi.org/10.1038/NGEO1680, 2013.

Petoukhov, V., Ganopolski, A., Brovkin, V., Claussen, M., Eliseev, A., Kubatzki, C., and Rahmstorf, S.: CLIMBER-2: a climate system model of intermediate complexity, Part I: Model description and performance for present climate, Clim. Dynam., 16, $1-17,2000$.
Roucoux, K. H., Tzedakis, P. C., de Abreu, L., and Shackleton, N. J.: Climate and vegetation changes 180,000 to 345,000 years ago recorded in a deep-sea core off Portugal, Earth Planet. Sc. Lett., 249, 307-325, 2006.

Sanchez-Goni, M. F., Eynaud, F., Turon, J. L., and Shackleton, N. J.: High resolution palynological record off the Iberian margin: direct land-sea correlation for the Last Interglacial complex, Earth Planet. Sc. Lett., 171, 123-137, 1999.

Sánchez Goñi, M. F., Rodrigues, T., Hodell, D. A., PolancoMartinez, J. M., Alonso-Garcia, M., Hernandez-Almeida, I., Desprat, S., and Ferretti, P.: Tropically-driven climate shifts in southwestern Europe during MIS 19, a low excentricity interglacial, Earth Planet. Sc. Lett., 448, 81-93, 2016.

Schmittner, A. and Galbraith, E. D.: Glacial greenhouse-gas fluctuations controlled by ocean circulation changes, Nature, 456, 373-376, https://doi.org/10.1038/nature07531, 2008.

Schmittner, A. and Lund, D. C.: Early deglacial Atlantic overturning decline and its role in atmospheric $\mathrm{CO}_{2}$ rise inferred from carbon isotopes $\left(\delta^{13} \mathrm{C}\right)$, Clim. Past, 11, 135-152, https://doi.org/10.5194/cp-11-135-2015, 2015.

Spratt, R. M. and Lisiecki, L. E.: A Late Pleistocene sea level stack, Clim. Past, 12, 1079-1092, https://doi.org/10.5194/cp-12-10792016, 2016.

Swingedouw, D., Braconnot, P., Delecluse, P., Guilyardi, E., and Marti, O.: Quantifying the AMOC feedbacks during a $2 \times \mathrm{CO}_{2}$ stabilization experiment with land-ice melting, Clim. Dynam., 29, 521-534, 2007a.

Swingedouw, D., Bopp, L., Matras, A., and Braconnot, P.: Effect of land-ice melting and associated changes in the AMOC result in little overall impact on oceanic $\mathrm{CO}_{2}$ uptake, Geophys. Res. Lett., 34, L23706, https://doi.org/10.1029/2007GL031990, 2007 b.

Yin, Q.: Insolation-induced mid-Brunhes transition in Southern Ocean ventilation and deep-ocean temperature, Nature, 494, 222-225, https://doi.org/10.1038/nature11790, 2013.

Yin, Q. Z. and Berger, A.: Insolation and $\mathrm{CO}_{2}$ contribution to the interglacial climate before and after the Mid-Brunhes Event, Nat. Geosci., 3, 243-246, https://doi.org/10.1038/ngeo771, 2010.

Yin, Q. Z. and Berger, A.: Individual contribution of insolation and $\mathrm{CO}_{2}$ to the interglacial climates of the past 800,000 years, Clim. Dynam., 38, 709-724, 2012. 